\title{
Distribution of tomato yellow leaf curl virus (TYLCV) in different parts of tomato plants: A serological perspective
}

\author{
Anil Kumar ${ }^{*}$, Anil Handa ${ }^{1}$ and Santosh Watpade ${ }^{2}$ \\ ${ }^{1}$ Dr. Y. S. Parmar University of Horticulture and Forestry, Nauni, Solan-173230 (Himachal Pradesh), INDIA \\ ${ }^{2}$ IARI Regional Station, Shimla-171004 (Himachal Pradesh), INDIA \\ *Corresponding author. E-mail: anildogra078@gmail.com
}

Received: January 25, 2016; Revised received: July 1, 2016; Accepted: October 15, 2016

\begin{abstract}
Serological detection of tomato yellow leaf curl virus in different parts of tomato through DAS-ELISA revealed that its branches have highest virus concentration followed by twigs, mature leaves and middle leaves. The samples derived from the branches gave highest mean OD value 0.517 whereas, the recorded mean OD values in case of twigs, mature leaves and middle leaves were $0.470,0.444$ and 0.419 , at $A_{405} \mathrm{~nm}$, respectively. The virus was not found to be present in flowers and fruits as indicated by lower mean OD values, i.e. 0.215 and 0.159 , respectively. On the basis of findings of the our experiment, the branches, twigs, mature leaves and middle leaves had high concentration of the virus and hence these parts could be used in the detection of TYLCV, whereas, flowers and fruits had very low titer of virus, thus, not recommended to be used for serological detection.
\end{abstract}

Keywords: Optical density, Serology, Tomato, Tomato yellow leaf curl virus

\section{INTRODUCTION}

Tomato (Solanum lycopersicum L.) is one of the most extensively cultivated vegetable crops in the world. The worldwide high consumption of tomato is primarily due to its flavor and high nutritive value. India is the fourth largest tomato producing country in the world after China, USA and Turkey (Kumar and Srivastava, 2013). Tomato is second most important remunerable solanaceous vegetable crop after potato (Sahu et al., 2013). In India tomato is cultivated during winter and summer seasons over an area of 0.88 million hectare, with $21.2 \mathrm{t} /$ ha productivity. In Himachal Pradesh it is grown over an area of 10.37 thousand hectare with an annual production of 430.79 thousand tones (Anonymous, 2015). It is one of the most remunerative cash crops of the growers of Solan, Sirmour, Mandi and Kullu areas of the Himachal Pradesh (NHB, 2013). Tomato yellow leaf curl virus (TYLCV) is one of the most important virus affecting tomatoes and thus, induces severe losses to crop from tropical to subtropical regions (Czosnek and Latterrot, 1997). The virus ranks third among top 10 plant viruses in the world (Reddy, 2006). Tomato yellow leaf curl virus is primarily transmitted by the sweet potato whitefly (Bemisia tabaci Gennadius) in a persistent and circulative manner (Melzer et al., 2009) but is not transmitted by the greenhouse whitefly (Trialeurodes vaporariorum) (Sugano et al., 2011). It is neither mechanically nor seed transmissible (Green and Kalloo, 1994; Cerkauskas, 2005; Czosnek, 2008). The virus has a quite broad host range, infecting plants belonging to solanaceae, malvaceae and leguminosae (Mansour and AlMusa, 1992; Oetting and Yunis, 2004). Natural occurrence of leaf curl disease was earlier confined to the tropical and subtropical areas but now it is considered as serious emerging problem in the low hills of subtemperate regions and as such pose a threat to the tomato cultivation in mid hills of the state Keeping in view the prevalence and the losses caused by the disease there is strong need of timely detection and diagnosis. The present study focuses on the stage of the crop and its parts which should be taken into consideration while planning for serological detection of the virus through enzyme linked immuno sorbent assay (ELISA).

\section{MATERIALS AND METHODS}

An experimental farm at Department of Vegetable Science, Dr Y S Parmar University of Horticulture and Forestry, Nauni (HP-India) was selected for conducting the experiment where tomato crop was growing. The crop was observed from transplanting to fruiting stage for development of symptoms of viral etiology, the data was recorded weekly. Plants showing typical leaf curl symptoms were marked and kept under observation and further, were subjected to Double antibody sandwich ELISA or DAS-ELISA for seroidentification via using ELISA kit procured from Bioreba Switzerland following the procedure described by Clark and Adams (1977) with some minor modifications. The various samples were taken from the in- 
fected plant and were washed with sterilized water. These samples were then placed in between the folds of blotting paper to absorb extra water. NUNC maxisorb microtiter plates were coated with TYLCV specific antibodies diluted in $1 \mathrm{X}$ coating buffer and were dispensed at the rate of $200 \mu \mathrm{l}$ per well. The microtiter plate was covered with aluminum foil and placed in a humid box and incubated at $30^{\circ} \mathrm{C}$ for 4 hours. After incubation was complete the plate was washed for 3-4 times in ELISA Plate washer assembly. The samples were crushed in $10 \mathrm{ml}$ of extraction incubated (1X) and the extracted sap was transferred at the rate of $200 \mu \mathrm{l}$ per well. The ELISA plate was again covered and placed in humid box and incubated in a refrigerator at $4^{\circ} \mathrm{C}$ overnight. Next day the plates were taken out and again washed for 3-4 times. In the last step the enzyme labeled secondary antibodies were added to trap the antigen proteins. The plate was again incubated at $30^{\circ} \mathrm{C}$ for 5 hours. Finally substrate along with
para-Nitrophenylphosphate (pNPP) was added to the antibody-antigen coated wells. The plate was incubated at room temperature in dark for 30-45 minutes for development of yellow color and the optical density values were taken at $405 \mathrm{~nm}$ in ELISA plate reader.

\section{RESULTS AND DISCUSSION}

Tomato plants showing prominent symptoms of leaf curl began to appear after 35 days of transplanting as the population of vector, Bemisia tabaci Gennadius started to build up. The initial symptoms were mild chlorosis along with upward curling of leaves which later developed into yellowing and acute curling of the leaves. Severely infected plants remained stunted and had very less number of fruits. Three such plants were marked and selected for obtaining test material, such as leaves, stems, flowers and fruits, further to be used in the serological detection of the virus through DAS ELISA. The data set out in Table 1 shows the serologi-

Table 1. Serological detection of TYLCV in the different parts of tomato through DAS ELISA (Values are mean of three replicates).

\begin{tabular}{cccccccc}
\hline Plant part & & OD A A05 $\mathbf{~ n m}$ & & $\begin{array}{c}\text { Mean } \\
\text { OD }\end{array}$ & +ve Control & -ve Control & $\begin{array}{c}\text { Healthy* } \\
\text { (Control) }\end{array}$ \\
\hline Twigs & 0.485 & 0.419 & 0.508 & 0.470 & 2.118 & 0.220 & 0.164 \\
Middle leaves & 0.398 & 0.421 & 0.439 & 0.419 & 2.118 & 0.220 & 0.164 \\
Mature leaves & 0.436 & 0.445 & 0.451 & 0.444 & 2.118 & 0.220 & 0.164 \\
Branches & 0.507 & 0.503 & 0.541 & 0.517 & 2.118 & 0.220 & 0.164 \\
Flowers & 0.214 & 0.209 & 0.197 & 0.215 & 2.118 & 0.220 & 0.164 \\
Fruits & 0.138 & 0.139 & 0.202 & 0.159 & 2.118 & 0.220 & 0.164 \\
\hline
\end{tabular}

*Healthy tomato plant showing no leaf curl symptom served as control

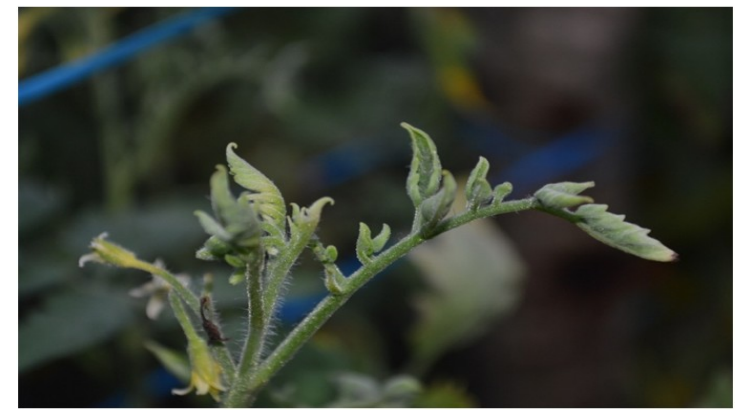

Fig. 1. Twigs of tomato showing cupping and upward curling symptoms.

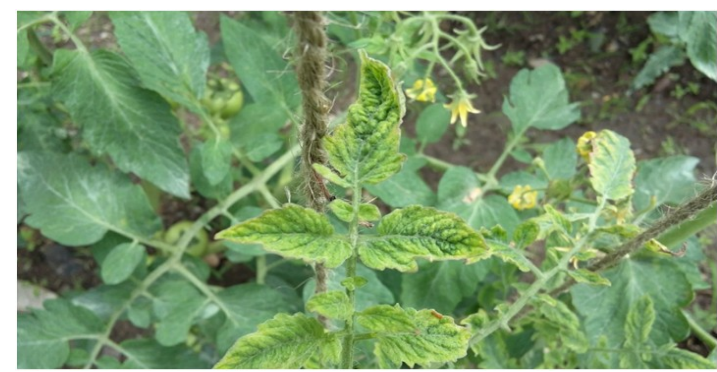

Fig. 3. Mature lower leaf of tomato showing severe yellow leaf curl symptoms.

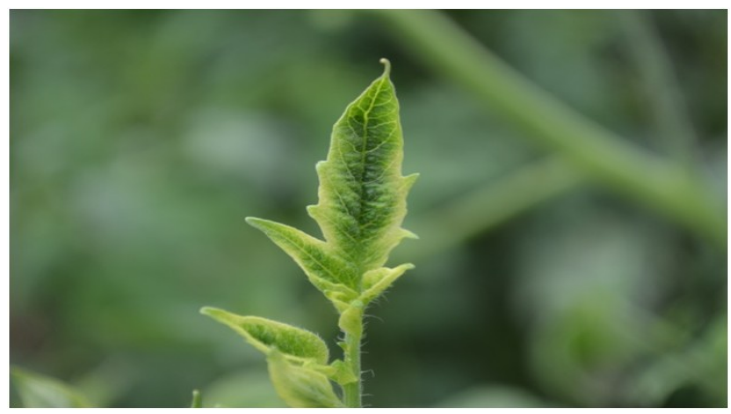

Fig. 2. Middle leaf of tomatoshowing yellow curling symptoms.

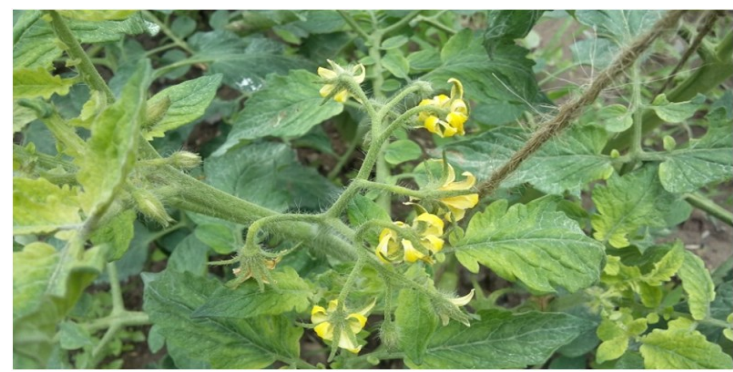

Fig. 4. Flowers of tomato used in experiment. 


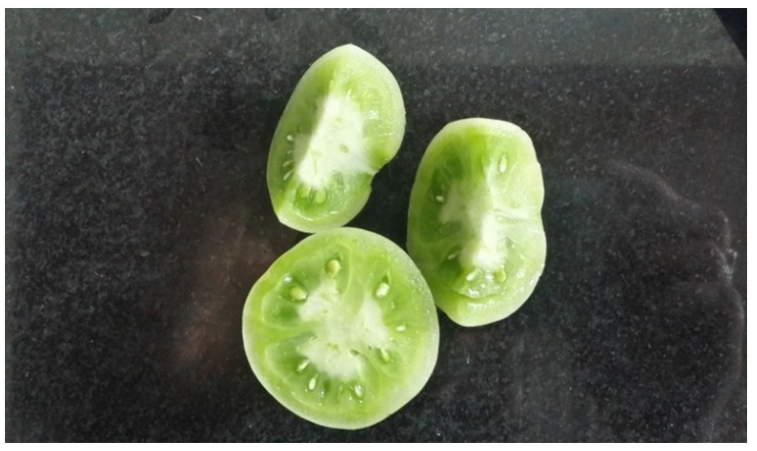

Fig. 5. Fruits of tomato used in experiment.

cal detection of TYLCV in the various parts of the tomato plant. It is clear from the obtained OD values that the branches of tomato had the maximum titer of the virions as the mean OD value is highest in case of branches i.e. 0.517 , followed by twigs (Fig. 1) having mean OD value 0.470 , followed by that of lower matured leaves (0.444) (Fig. 3) and finally by middle young leaves 0.419 (Fig. 2). The virus was undetectable in the samples comprising of flowers and fruits (Figs. 4 and 5) as shown by the lower mean OD values i.e. 0.215 and 0.159 which is less than that of negative control (0.220). Devaraja et al. (2005) also detected TYLCV in tomato through DAS-ELISA and observed OD values ranging from 0.64 to 2.04 at $\mathrm{A}_{405} \mathrm{~nm}$, which are similar to the OD values recorded in our experiment. Ajlan et al, (2007) and Kushwaha et al.(2010) have also earlier used DAS ELISA technique for the detection of TYLCV from tomato but no worker has described the virus distribution among the various parts of the plants. Fig. 6 shows the microtiter plate depicting serological reaction of various samples. The results further suggest that any part of plant could be used in the serological detection of TYLCV from tomato except flowers and fruits.

\section{Conclusion}

The results in this study has shown that TYLCV can be detected from any part of tomato plant including twigs, middle leaves, mature leaves, branches, however, the branches have more titer of the virions. The flowers and fruits should not be used for serological detection of TYLCV as the virus is absent in both these parts. Thus, twigs branches, middle and mature leaves should be considered as ideal material for serological detection of TYLCV whereas, flowers and fruits should be avoided. These considerations will surely be helpful in reducing the unnecessary consumption and wastage of costly ELISA reagents and time.

\section{REFERENCES}

Ajlan, A.M., Ghanem, G.A.M and Abdulsalam, K.S. (2007). Tomato yellow leaf curl virus (TYLCV) in Saudi Arabia: Identification, partial characterization and virus-

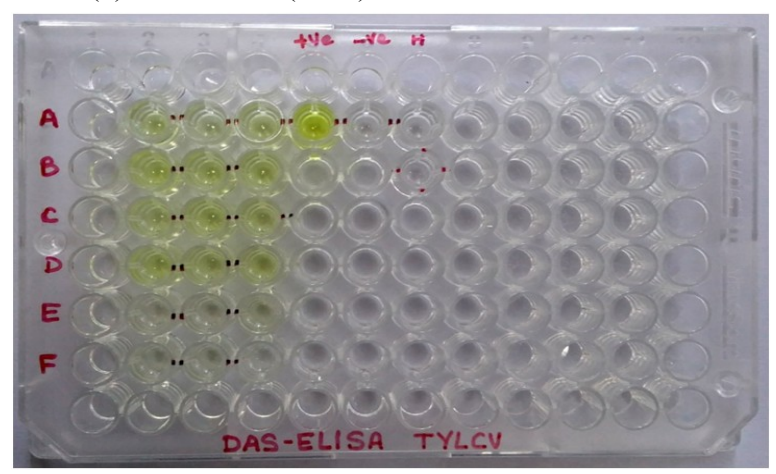

Fig. 6. ELISA plate showing serological detection of TYLCV in the different parts of tomato through DAS ELISA-A: Twigs, B: Middle leaves, $C$ : Mature leaves, D: Branches, $E$ : Flowers, F: Fruits.

vector relationship. Arabian Journal of Biotechnology, 10(1): 179-192

Anonymous. (2015). Handbook of indian horticulture database, NHB, Gurgaon. department of agriculture and cooperation, Ministry of Agriculture, Government of India, New Delhi. pp 48

Cerkauskas, R. F. (2005). Tomato disease-Tomato Yellow Leaf Curl Virus (TYLCV). Asian Vegetable Research and Development Center Report, AVRDC Publication, No. 04-610.

Clark, M.F. and Adams, A.N. (1977). Characteristics of the microplate method of enzyme-linked immunosorbent assay for the detection of plant viruses. Journal of General Virology, 34: 475-483

Czosnek, H. (2008). Tomato yellow leaf curl Virus. Encyclopedia of Virology, Vol. 5, Elsevier, Oxford, pp 138-145

Czosnek, H. and Laterrot, H. (1997). A world wide survey of tomato yellow leaf curl virus. Archives of Virology, 142: 1391-1406

Devaraja, Narayanaswamy, K., Savithri, H.S. and Muniyappa, V. (2005). Purification of tomato leaf curl Bangalore virus and production of polyclonal antibodies. Current Science, 89(1): 181-183

Green, S.K. and Kalloo, G. (1994). Leaf curl and yellowing viruses of pepper and tomato: An overview. AVRDC Tech. Bull. No 21

Kumar, S. and Srivastava, K. (2013). Screening of tomato genotypes against early blight (Alternaria solani) under field condition. The Bioscan, 8(1): 189-193

Kushwaha, N., Singh, A.K., Chattopadhyay, K. and Chakraborty, S. (2010). Recent advances in geminivirus detection and future perspectives. The Journal of Plant Protection Sciences, 2(1): 1-18

Mansour, A. and Al-Musa, A. (1992). Tomato yellow leaf curl virus: host range and virus relationships. Plant Pathology, 41: 122-125

Melzer, M.J., Ogata, D.Y., Fukuda, S.K., Shimabuku, R., Borth., W.B., Sether, D.M, Hu, J.S. (2009). Tomato yellow leaf curl. CTAHR PD-70 (http://www.ctahr. hawaii.edu/oc/freepubs/pdf/RES-078.pdf).

NHB (2013). Handbook of Indian Horticulture Database. NHB. Gurgaon, Haryana, India. http://nhb.gov.in

Oetting, R., and Yunis, H. (2004). Field guide to common insects, mites and diseases of greenhouse grown sweet peppers and tomatoes. Kfar Qari: Hakohav Press. pp 69

Reddy, B.A. (2006). Molecular characterization, epidemiol- 
Anil Kumar et al. / J. Appl. \& Nat. Sci. 8 (4): 1827-1830 (2016)

ogy and management of tomato leaf curl virus (ToLCV)

in Northern Karnatka. Ph.D thesis, Department of Plant pathology, College of Agriculture, Dharwad, University of Agricultural Sciences, Dharwad, India.
Sahu, D.K., Khare, C.P., Singh, H.K., and Thakur, M.P. (2013). Evaluation of newer fungicide for management of early blight of tomato in Chhattisgarh. The Bioscan, 8(4): 1255-1259 